\title{
„Együtt gyógyul a szívünk” párkapcsolaterösítő program a kardiológiai rehabilitáció folyamatában
}

\author{
„Healing Heart Together”, relationship strengthening programme \\ in the process of cardiological rehabilitation
}

Gyenis-Kátay Noémi ${ }^{1}$, Török Szabolcs ${ }^{2}$

1 Semmelweis Egyetem, Mentális Egészségtudományok Doktori Iskola, 4/3 alprogram

2 Semmelweis Egyetem, Mentálhigiéné Intézet

A szívbetegséggel foglalkozó kutatások során egyértelmúvé vált, hogy a betegek partnerei nem mellözhetök a rehabilitációs folyamatban, hiszen a párkapcsolati elégedettség erőteljesen befolyásolja az egészségügyi mutatókat pozitív és negatív irányban egyaránt. A „Együtt gyógyul a szívünk" érzelemfókuszú párterápiás módszertannal dolgozó, specifikusan szívbeteg párok számára szervezett edukatív csoport a balassagyarmati és a salgótarjáni kórházban 2018-ban egy EFOP pályázat keretében valósult meg. Jelen tanulmány célja az „Együtt gyógyul a szívünk" csoportfolyamat és a szívbetegség párkapcsolatra gyakorolt hatásának bemutatása.

Over the course of researches dealing with heart ailment, it has become evident that patiens' partners cannot be overlooked in the cardiac rehabilitation process since relationship satisfaction has significant influence on health indicators both in positive and negative ways. The "Healing heart together" ("Együtt gyógyul a szívünk") educational group working with the method of emotionally focused couple therapy was specifically organised for couples dealing with cardiac diseases in the main hospitals of Balassagyarmat and Salgótarján, and was funded by an EU project. The present article aims to present the "Együtt gyógyul a szívünk" group process and the effect of the cardiac disease exerted on the relationship.

\section{AZ ÁPOLÓ HÁZASTÁRSAK/ PARTNEREK SZEREPE A KARDIOLÓGIAI REHABILITÁCIÓ SORÁN}

A fejlett országokban az iszkémiás szívbetegség vezető haláloknak számít, a WHO felmérései szerint évente 17,9 millióan halnak meg világszerte valamilyen szívbetegségben, és az összes halál megközelítőleg 31\%-a a szívbetegség valamilyen válfaja miatt következik be. A koszorúér megbetegedései mellett egyéb, gyakori szívbetegséget is számontartunk, mint például a nem koszorúsér eredetű szívizombetegség, szívelégtelenség, szívritmuszavar, magas vérnyomás. A megbetegedések kezelése során az orvos és a beteg közös célja, hogy lehetőség szerint a kockázati tényezők csökkentésével elkerüljék a súlyos állapot ismétlődését.

Az egészségügyi ellátásban mára már evidencia, hogy a szívproblémával kórházba kerülők számára rehabilitációs programot kell szervezni, melynek része az intézeti, általában 3 hetes szakasz után egy hosszabb, 6-12 hetes rehabilitációs program. A rehabilitáció része az egészségi állapotfelmérésen, dietetikussal való konzultáción és a megfelelő testmozgás bevezetésén túl a stressz csökkentése, és az életmódbeli változások (dohányzásról leszokás, alkohol mértékletes fogyasztása) kihívásainak pszichés támogatása is. A pszichés támogatás fókusza a stressz kezelése például relaxációs technikák alkalmazásával. Egy 2017-es, iszkémiás szívbetegek pszichoszociális stressz szintjét mérő vizsgálat, mely független rizikótényezőként azonosítja a depressziós tüneteket, a magányt és a rossz egyéni financiális állapotot, felhívja a figyelmet a partner fontosságára a kezelésben [11]. Az 1. ábra jól mutatja az egyedül élők és a nem egyedül élők közötti különbséget a kardiovaszkuláris betegség okozta halálozás tekintetében.

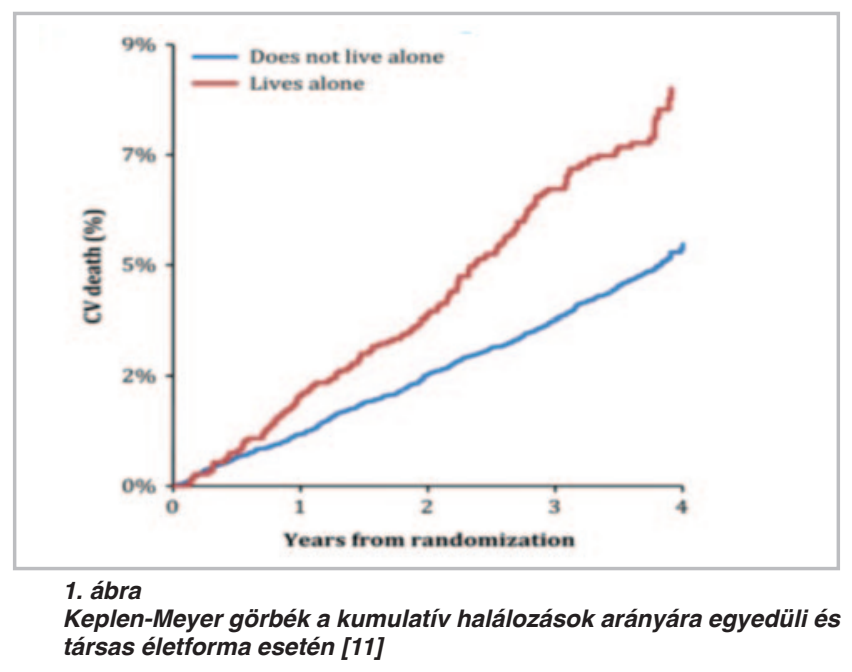

A krónikus betegséggel élő személyek párkapcsolatában nemcsak a beteg él át az átlagosnál nagyobb stresszt, de a partner is, a folyamat kísérőjeként. Ennek a területnek a kutatása jóval később kezdődött, mint a rehabilitációs programok elindítása. A „gondozók” olyan nem fizetett ápolók, akik hoszszú ideig gondoskodnak egy közeli hozzátartozóról [1].

Bouchard kutatásai szerint [2] a partner, aki sokszor tehetetlennek érzi magát, még nagyobb stresszt él át, mint a betegséggel érintett személy. Különösen nagy stressz nehezedik a házastársukat gondozókra. A házastársukat vagy szülőket gondozók 2,5-szer nagyobb eséllyel halnak meg szívbetegség következtében, mint azok, akik kevesebb feszültséggel, távolabbi személyt ápolnak. A gondozók kevés- 
sé figyelnek oda saját jóllétükre, gyakran élnek a kórházi kezelés időtartama alatt is rosszabb körülmények között, mint a betegek, gyakran nem szoknak le a dohányzásról, ivásról, keveset és nyugtalanul alszanak, krónikus szorongást élnek át hosszú időn keresztül a tehetetlenség és a kontrollvesztés érzése miatt, és ez a tünet a legtöbb esetben a betegség után egy évvel is jelen van. A „magas intenzitású ápolást” végzők (több mint 14 óra két éven keresztül) között megduplázódik a magas vérnyomás kockázata.

Bár látványos és bizonyított a betegek hozzátartozóinak (elsősorban házastársainak) túlterheltsége, és körükben a szívbetegség kockázatának növekedése, mégis kevés rehabilitációs program foglalkozik a párra nehezedő érzelmi, pszichés terhek könnyítésével.

\section{SZÍVBETEGSÉG ÉS PÁRKAPCSOLAT}

\section{A szívbetegség hatása a párkapcsolatra}

A kutatások alapján a párkapcsolati feszültségek összefüggésben vannak a szívbetegségek kialakulásával és a meglevő betegség előrehaladásával még akkor is, ha az egyéb kockázati tényezőket (vérnyomás, testtömegindex, életkor) korrigálják az elemzésnél (lásd 2. ábra) [3-6].

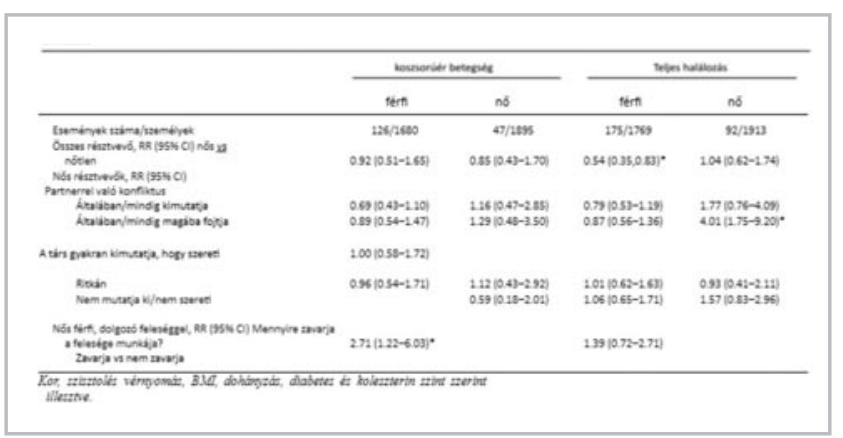

2. ábra

A koszorúér-betegség és kumulatív halálozás 10 éves, multivariábilis, illesztett relatív rizikója férfiaknál és nóknél [12]

Barger [7] amerikai, párkapcsolatban élő 1430 felnőtt sejtjeinek öregedését vizsgálta a telomer hosszuk összehasonlításával. A társas támogatás formáit elemezve összehasonlították a házastársat támogató személyként említőket a támogató személyként nem említőkkel. Az eredmény magáért beszél, az összes egyéb társas támogatási forma közül a partner támogatása a legjelentősebb, és ez az a támasz, ami leginkább hat a telomer hosszára, így lassítva a sejtek öregedését és növelve a fizikai egészség fenntartásának lehetőségét (3. ábra)

\section{A mindennapok visszatérő konfliktusai}

A házastársi kapcsolat dinamikája szempontjából tekintsük át azt a folyamatot, ahogy kialakul az a visszatérő ciklus, mely olyan napi feszültségekhez vezet, ami állandósíthatja a kapcsolatban megélt stressz magas szintjét, ezzel rontva a kapcsolati elégedettséget.

A szívbeteg partner megváltozott teherbírása és aktivitási készsége az élet több területén (fizikai munkák, szexualitás, munkavégzés, szabadidős programok) alapvetően változtatja

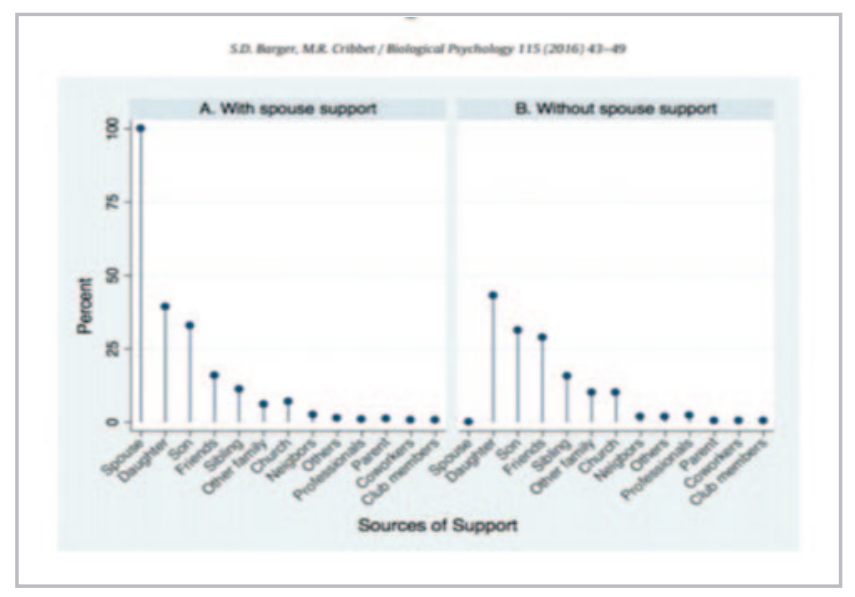

3. ábra

A társas támogatás forrásai házas felnōtteknél, akik házastársukat támogató személyként jelölték meg [7]

meg a férfi/női szerepek alakulását. Az addig aktív fél támogatásra, gondoskodásra szorul, az egészséges partner ápolói minőségben, állandó aggódással figyeli beteg partnere hogylétét. Az addig támaszt nyújtó, aktív partner kiszolgáltatottsága hatással van önértékelésére: gyengének, erőtlennek éli meg magát, ez dühöt, agressziót, vagy fásultságot eredményez, melyet nem tud az addig megszokott módszerekkel, például fizikai megterheléssel levezetni, így stresszszintje magas. Amikor aggódó partnere gyógyszerei bevételére és az egészséges életmódra figyelmezteti, „beteg énjét” szólítja meg, és sokszor elutasítással, daccal találkozik. Ettől az „ápoló” partner átéli tehetetlenségét, és aggódni kezd, hiszen egy módon segítheti aktívan partnerét, azzal, hogy felügyeli rehabilitációs folyamatát. A szívbeteg partner elutasításától párja aggódni kezd, kétségbe esik, hogy valami baj történik, és minden módszerrel arra próbálja rávenni, hogy vegye be gyógyszerét. Erre a beteg egyre erősebb elutasítással, önállósága és cselekvőképessége kihangsúlyozásával válaszol, és a gyógyszer beszedéséből hatalmas vita kerekedik. A beteg partner egyedül marad tehetetlen dühével, amit korlátozottsága okoz, az ápoló partner pedig nemcsak a félelmet éli át újra, hogy szívbeteg párja akár meg is halhat, hiszen nem vigyáz magára, hanem úgy is érzi, csak neki fontos ennek megelőzése, hiszen a beteg nem figyel gyógyszereire. Ez a mindennapi helyzet válik a pár „ördögi körévé” az érzelemfókuszú párterápia szemléletében. Az ördögi kör sajátja, hogy végtelen ciklust alkot, az egyik minél jobban mondja, a másik annál jobban visszahúzódik, a későbbiekben pedig mindketten magányosak maradnak.

Az Ottawai Egyetemen Kardiológiai Intézetében Heather Tulloch és munkatársai évek óta kutatják a szívrehabilitáció eredményességét, és a lehetséges módszertani változtatásokat, melyekkel a már szívbetegséggel élő páciensek számára a legeredményesebb kezelést biztosíthatják, hogy betegségük a lehető legkevésbé rontsa életminőségüket. Kutatásaik a párkapcsolat vizsgálatára is fókuszálnak, figyelembe véve a már említett szakirodalmi adatokat és az Intézetben szerzett tapasztalataikat. Konkrét eredményeik vannak arra, milyen módon befolyásolják a párkapcsolati feszültségek a betegek fizikai jóllétét. 
Tulloch [8] a párkapcsolati interakciók vizsgálatánál kimutatta, hogy a vitáknál vérnyomás-emelkedés, a támogató interakcióknál vérnyomáscsökkenés tapasztalható, valamint a támogató párkapcsolatban élők jobban betartják az előírásokat, szorgalmasabbak és türelmesebbek a rehabilitáció során.

Tulloch vizsgálatai azért is jelentősek, mert nemcsak a fizikai tünetek meglétére vagy hiányára összpontosít, hanem fókuszcsoportos interjú segítségével feltárta a szívbetegséggel élő párok kapcsolatában megjelenő változásokat, és megfogalmaztatta azokat a területeket, melyekben az érintett pároknak segítségre lenne szükségük [8]. Ez a konkrét igényfelmérés nagy előrelépést jelentett a párkapcsolat-fókuszú segítségnyújtásban a szívrehabilitáció során, mivel addig legtöbbször kognitív eszközöket alkalmaztak, mely inkább a pszichoedukációra fókuszál, nem érinti a mindennapi, kapcsolatban történt változásokat. Egy 2013-as vizsgálat, ami a rehabilitáció során kifejezetten a betegeket és partnereiket együtt kezelő csoportok hatékonyságát vizsgálta, szerény eredményre jutott [9]. Bár az intervenciók kis mértékben javították az egészséggel kapcsolatos életminőséget, a vérnyomást, ismereteket adtak mindkét félnek, ezzel csökkentették a résztvevők szorongását, mégis az eredmények nem mutattak kiugró hatékonyságot, a depressziós tünetek, és a szorongás sem csökkent szignifikánsan. Ezek a kutatások nem vizsgálták a párkapcsolati elégedettséget, mint tényezőt. Az említett, Heather Tulloch [8] által készített interjú alapján pontos képet kaphatunk a szívbetegséggel érintett párok igényeiről. A párok a következő igényeket fogalmazták meg: praktikus segítség a betegség kezelésével, az azzal való együttéléssel kapcsolatban, sorstársakkal való beszélgetés, a tapasztalatok megosztása, a kapcsolat erősödése.

\section{AZ „EGYÜTT GYÓGYUL A SZÍVÜNK” CSOPORTFOLYAMAT BEMUTATÁSA}

A „Együtt gyógyul a szívünk” az érzelemfókuszú párterápia kapcsolaterősítő csoportprogramjának egy változata, kifejezetten a szívbetegséggel küzdő párok igényeire kidolgozva. A kötődéselméletre építő csoport hangsúlya a biztonságos kötődés megerősítésére vagy kialakítására helyezi a hangsúlyt. Az elérhető és válaszkész partnerkapcsolat bármilyen nehézség esetén hatékony védőfaktor lehet a szorongás és a depresszió leküzdésében. A program során a párok beszélgetéseket folytatnak egymással, sorstársaikkal. Minden téma előtt egy bevezető előadás segíti a ráhangolódást és a pszichoedukációt. A beszélgetések során a résztvevők információt kapnak a szív egészsége és a kötődés biztonságossága közötti összefüggésről, megoszthatják a sorstársi közösségben tapasztalataikat ápolóként és betegként egyaránt, és megtanulhatják a páros beszélgetések alkalmával kifejezni kapcsolódási vágyukat és megerősítésre váró igényeiket. Ez a folyamat növeli a párkapcsolati elégedettséget és a problémamegoldást. Acsoportok hatékonyságát mérő kutatás [10] szignifikáns változást mutatott a kapcsolati elégedettségben, a lelki egészségben és különböző, életminőséget érintő kérdésekben. A résztvevők elégedettségi mutatója magas volt $(4,7 / 5)$.

\section{A pilot vizsgálat tapasztalatai (Balassagyarmat, Salgótarján, 2018. november)}

Az „Együtt gyógyul a szívünk” csoport magyar adaptálása és a hatásvizsgálati kutatás pilot vizsgálata 2018-ban az EFOP 5.2.5.-18-2018 - 00011 számú Lelki Egészség és jóllét az életúton át - Komplex támogató program Nógrádban pályázat keretében valósult meg Balassagyarmaton és Salgótarjánban (Dr. Kenessey Albert Kórház-Rendelőintézet, Szent Lázár Megyei Kórház). A két csoportban összesen 26 szívbeteg pár vett részt kétszer 3 napos program keretében. A pilot csoport alkalmai fontos szempontokra mutattak rá. A túlnyomórészt idősebb párok számára kiemelt jelentőségű volt az erőforrások, a meglevő pozitív tapasztalatok erősítése. Sokuknál jellemző az érzések elfojtása, vagy traumák, fájdalmas múltbeli tapasztalatok jelenléte. A gyakorlati tapasztalatok alapján a szívbetegség kórelőzményében nagyon gyakran fordul elő kapcsolati veszteség, halál. A fiatalabb párok a csoportban nyitottabbak voltak a mélyebb feldolgozásra, az idősebb párok esetében inkább a kreatív egyéni megoldásokat, a meglevő lehetőségeket volt fontos hangsúlyozni. A szerepek felcserélődésébő adódó feszültségek oldódásában a szégyenérzet kimondása és a helyzet legalizációja segített, így az addig tabuként kezelt témák kimondhatóvá, megoszthatóvá váltak. A kimondási folyamatnak fontos része volt a sorstársi csoport, ahol a közös tapasztalatok validálták a résztvevők érzéseit.

A pilot vizsgálat alapján megfogalmazott szempontok a csoportok szervezéséhez:

- A célcsoport számára a kórházi környezetben rendezett heti rendszerességű csoportalkalmak szervezése lenne az ideális (8-szor 3 óra). A heti rendszeresség lassan, lépésről lépésre ad lehetőséget az érzelmi kommunikáció mélyítésére, gyakorlására, ez az amúgy elfojtásban, tagadásban élő betegek számára felvehetőbb ritmus. Ezen kívül nagyobb a támasznyújtási lehetősége egy hoszszabb, 8 héten át tartó folyamatnak.

\section{- A tartalmi hangsúly}

- az erőforrásokon van, különösen idős párok esetében

- a beteg partner támaszkeresési lehetőségeinek megkeresésén és tudatosításán, valamint, a gondozó partner szempontjából, a támasznyújtás megélésén van. Ez az újfajta érzelmi intimitás az egyensúly felé mozdíthatja a felborult dinamikát.

- A csoportvezető érzelmi jelenléte, az érzések validálása az ő személyén keresztül különösen is kiemelt jelentőségú ebben a célcsoportban, ahol a nehéz érzések kezelésére, kifejezésére nincsenek stratégiák, és nehéz kimondani megterhelő mondatokat az élet végességével kapcsolatban. Az előadások során elhangzott érzelmi validációk utat nyithatnak az egyéni feldolgozás, érzelmi kifejezés felé.

A csoportlehetőség fogadtatása egyértelműen pozitív volt mind a kezelőorvosok, mind a betegek körében. A program szervezése alatt kiemelt jelentőségű volt azon orvosok segítsége, akik a szívrehabilitáció folyamán több évtizedes kapcso- 
latban állnak betegeikkel, kísérik életüket, gyógyulásukat. Az ő mélyen emberséges, segítőkész hozzáállásuk tette lehetővé, hogy a lehetőségre nyitott párok hallhassanak a lehetőségről. Az orvosi és pszichológusi munka ilyen összefonódása kiváló példája a betegek gyógyulása érdekében végzett integrációs szemléletű terápiának, melyben a kezelőorvos és a beteg közötti bizalmi kapcsolat ad olyan alapot a betegek számára, hogy nyitottá válnak egy számukra ismeretlen, elsőre akár ijesztő csoportfolyamaton való részvételre. A betegekkel és kezelőorvosaikkal találkozva úgy éreztem, ebben a bizalmi körben történhet és történik a gyógyulás, és ezek a mélyen emberséges, lelkiismeretes kezelőorvosok azok a szakemberek, akikkel együtt dolgozva a kórházi munka fizikális szempontjai mellett a pszichés segítségnyújtás szempontok is egyre inkább beépülhetnek a kórházi mindennapokba.

\section{IRODALOMJEGYZÉK}

[1] Parry M: Caregiver burden and cardiovascular disease: can we afford to keep the health of caregivers in Canada invisible? Canadian Journal of Cardiology, 2019. 35(10): p 1267-1269. https://doi.org/10.1016/j.cjca.2019.06.025

[2] Bouchard Ket al.: Reducing Caregiver Distress and Cardiovascular Risk: A Focus on Caregiver-Patient Relationship Quality. Can J Cardiol, 2019. 35(10): p. 1409-1411. https://doi.org/10.1016/j.cjca.2019.05.007

[3] Eaker ED et al.: Marital status, marital strain, and risk of coronary heart disease or total mortality: the Framingham Offspring Study. Psychosom Med, 2007. 69(6): p. 509-13. https://doi.org/10.1097/PSY.0b013e3180f62357

[4] Robles TF et al.: Marital quality and health: a meta-analytic review. Psychol Bull, 2014. 140(1): p. 140-187. https://doi.org/10.1037/a0031859

[5] Smith TW et al.: Marital discord and coronary artery disease: a comparison of behaviorally defined discrete groups. J Consult Clin Psychol, 2012. 80(1): p. 87-92. https://doi.org/10.1037/a0026561

[6] Uchino BN: Social support and health: a review of physiological processes potentially underlying links to disease outcomes. J Behav Med, 2006. 29(4): p. 377-87. https://doi.org/10.1007/s10865-006-9056-5

[7] Barger SD and Cribbet MR: Social support sources matter: Increased cellular aging among adults with unsupportive spouses. Biological psychology, 2016. 115: p. 43-49. https://doi.org/10.1016/j.biopsycho.2016.01.003

[8] Tulloch $\mathrm{H}$ et al.: Learning a new way of living together: a qualitative study exploring the relationship changes and intervention needs of patients with cardiovascular disease and their partners. BMJ open, 2020. 10(5): p. e032948. https://doi.org/10.1136/bmjopen-2019-032948

[9] Reid J, Ski CF and Thompson DR: Psychological interventions for patients with coronary heart disease and their partners: a systematic review. PloS one, 2013. 8(9): p. e73459. https://doi.org/10.1371/journal.pone.0073459

[10] Tulloch HE and Greenman PS: In sickness and in health: relationship quality and cardiovascular risk and management. Current Opinion in Cardiology, 2018. 33(5): p. 521-528. https://doi.org/10.1097/HCO.0000000000000553

[11] Hagström E: Psychosocial stress and major cardiovascular events in patients with stable coronary heart disease. Journal of Internal Medicine, 2017, 283 (1): p. 8392, (10.1111/joim.12692) https://doi.org/10.1111/joim.12692

[12] Eaker E, Sullivan L, Kelly-Hayes $M$ and al.: Marital Status, Marital Strain, and Risk of Coronary Heart Disease or Total Mortality: The Framingham Offspring Study. Psychosomatic Medicine, 2007, 69, 509-513. https://doi.org/ 10.1097/PSY.0b013e3180f62357

\section{A SZERZŐK BEMUTATÁSA}

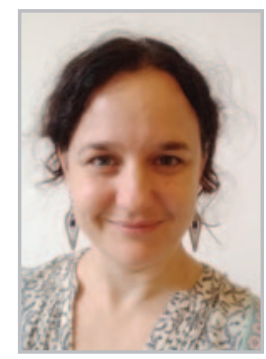

Gyenis-Kátay Noémi pszichológus másoddiplomát szerzett pedagógusi végzettség után a Debreceni Egyetemen. Családterapeutaként és pszichológusként dolgozik az Antropos Mentálhigiénés Egyesületben és a Habitus Alapítványnál, külsős oktató a Semmelweis Egyetem (SE) Mentálhigiéné képzésén. Több alkalommal vezette az „Ölelj át!” és „Együtt gyógyul a szívünk” csoportokat. Doktori kutatása az SE Mentális Egészségtudományok Doktori Iskolájában kezdte meg 2020 őszén. Témája az érzelemfókuszú párterápia szívbeteg párok számára kidolgozott csoportváltozatának hatásvizsgálata. A gyakorlati munka elkötelezett híveként célja a szívbeteg rehabilitáció folyamatába olyan hatékony, kapcsolati fókuszú program beépítése, ami a rehabilitáció folyamatába illeszkedve lehetőséget nyújt a betegek és partnereik számára a szívbetegség miatt megváltozott életvitelükhöz való alkalmazkodásban.

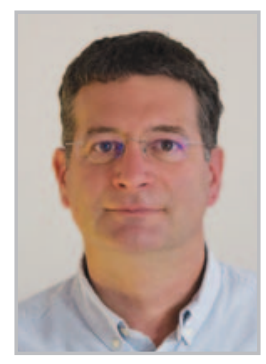

Dr. Török Szabolcs az orvosi diploma megszerzését követően gyermekgyógyász majd pszichoterapeuta szakorvosi szakvizsgát tett. Kezdetben a SE ÁOK II. Gyermekgyógyászati Klinikáján dolgozott, jelenleg a SE EKK Mentálhigiéné Intézetében egyetemi docens. Témavezető a SE Mentális Egészségtudományok Doktori Iskolájában. Család és Párterapeuta végzettsége megszerzését követően az ICEEFT nemzetközi szervezettől megkapta az „Akkreditált Érzelem Fókuszú Terapeuta" címet, elsőként Magyarországon. EFT szemléletben vezetett párterápiás tevékenységet jelenleg az Antropos Mentálhigiénés Módszertani Központban végez. 